\title{
VLIV LITOLOGIE A MORFOLOGIE VYSOKOGRADIENTOVÝCH KORYT NA DNOVÉ SEDIMENTY: PŘíKLADOVÁ STUDIE VODNÍHO TOKU KOBYLSKÁ (VSETÍNSKÉ VRCHY, ČESKÁ REPUBLIKA)
}

\author{
Effect of lithology and morphology of high-gradient channels on bed sediments: a case \\ study of the Kobylská Stream (Vsetín highlands, Czech Republic)
}

\author{
Tereza Macurová $₫$, Václav Škarpich, Tomáš Galia \\ Katedra fyzické geografie a geoekologie PřF OU, Chittussiho 10, 71000 Ostrava-Slezská, Ostrava
}

Key words: bed sediments, headwater stream, channel morphology, grain-size analysis, Kobylská stream, Vsetín highlands, Outer Western Carpathians

\begin{abstract}
High-gradient streams are integral parts of the fluvial systems, which connect the mountainous landscapes with lowland rivers in the sense of water and sediment transport. We analysed downstream grain-size characteristics of bed sediments and sphericity of grains with respect to the local flysch lithology and channel geometry in the $5.4 \mathrm{~km}$ long reach of the high-gradient Kobylská Stream (the Vsetin highlands, Outer Western Carpathians, Czech Republic). Results showed a high variability of bed-sediment sizes in the longitudinal course of the Kobylská stream. This condition is given by the occurrence of anthropogenic impact in the studied channel (local bank stabilisations, grade-control structures) and lateral sediment input from the adjacent landslides and bank failures. The lithology of the flysch nappe structure of the basin significantly influenced variations of bed sediment grain-sizes. Different bedrock resistance resulted into inverse correlation between the local river gradient and related bed grain-sizes. Especially the mudstone bedrock layers had significant impact on the fining of bed sediment in the upper steep part of the basin $\left(D_{50} \leq 40 \mathrm{~mm}\right)$ and by contrast, sandstone bedrock caused the coarsening of the bed sediment in the middle and lower parts $\left(D_{50}\right.$ up to $\left.50 \mathrm{~mm}\right)$ characterised by lower bed gradients.
\end{abstract}

Úvod

Vysokogradientové toky jsou důležitými částmi fluviálního systému. Tvoř́ zdrojové oblasti vody a sedimentů v povodí a propojují tak nížinné oblasti s horskými (Schumm 1977). Vysokogradientové toky jsou definovány jako strmá koryta s gradientem vyšším nebo rovným $0,002 \mathrm{~m} / \mathrm{m}$, jejichž dno je vyplněno štěrkovou, valounovou či balvanitou frakcí nebo je tvořeno skalním podložím. Niva je u těchto tokủ prostorově omezena přiléhajícími svahy nebo zcela chybí (Wohl, Merritt 2008). U těchto toků obvykle převažuje transport a odnos sedimentů nad jejich dodávkou, která je realizována především prostřednictvím přilehlých svahů. Mezi hlavní zdrojnice se proto primárně řadí břehové nátrže, sesuvy nebo blokovobahenní proudy, prrípadně eroze dna koryta. Typickým rysem těchto toků je také rozkolísanost průtoků (Montgomery, Buffington 1997, 1998). Erodované sedimenty mají v závislosti na hydrologickém režimu a morfologických vlastnostech koryta přirozený potenciál se transportovat. Př̀i lokálním poklesu unášecí schopnosti toku, např́iklad v důsledku rozšiřrení a snížení sklonu koryta, mohou převažovat procesy depozice za vzniku prostorově omezených štěrkových akumulací (Galia, Škarpich 2016). Tato morfologie koryta poté může zpětně ovlivňovat pohyb a transport sedimentárního materiálu (Brierley, Fryirs 2005).

Charakteristické pro vysokogradientové toky flyšových Karpat v České republice je antropogenní ovlivnění

$\square$ tereza.macurova@osu.cz

DOI: https://doi.org/10.5817/GVMS2018-1-2-21 přirozených fluviálních procesů formujících koryto a přilehlou říční nivu. Tento stav se pak odráží ve změnách distribuce akumulovaných dnových sedimentů v podélném průběhu toku. Mezi hlavní antropogenní vlivy je v současnosti možné zahrnout především hrazení toků a stabilizace břehů (Škarpich et al. 2010; Galia et al. 2016; Škarpich et al. 2016; Galia, Škarpich 2017). Méně probádaný je pak vliv litologie na zrnitostní parametry dnových sedimentů v souvislosti s výskytem např. odolnějších pískovcových hornin a méně odolných jílovcových hornin, z nichž jsou erozními procesy sedimenty dodávány do koryta. Tato studie přináší na základě analýzy dnových sedimentů informace o vlastnostech a chování korytového systému vysokogradientového toku Kobylská v souvislosti s procesy ovlivněnými litologickými poměry v povodí. Mezi hlavní cíle práce se kromě rozšíření výše zmíněných poznatků o vysokogradientových tocích $\mathrm{v}$ dané oblasti řadí zhodnocení zrnitostních parametrů dnových sedimentů Kobylské (i) v podélném průběhu vodního toku v kontextu výskytu zdrojnic sedimentárního materiálu a antropogenního ovlivnění a (ii) v souvislosti s geometrickými parametry koryta, sklonem a šírkou.

\section{Vymezení studovaného území}

Zájmovou oblastí výzkumu bylo povodí vodního toku Kobylská ve Vsetínských vrších (obr. 1). Kobylská pramení ve výšce $833 \mathrm{~m}$. m. pod vrcholem Tanečnice (911 m n. m.) a ústí zprava do Vsetínské Bečvy ve výšce $474 \mathrm{~m} \mathrm{n}$. m. Celková plocha povodí činí $6,9 \mathrm{~km}^{2}$ a délka toku je 5,4km. Pro dnové sedimenty Kobylské je typická štěrková frakce petrograficky tvořená nejčastěji pískovci, jílovci a v menší míře také slepenci. 


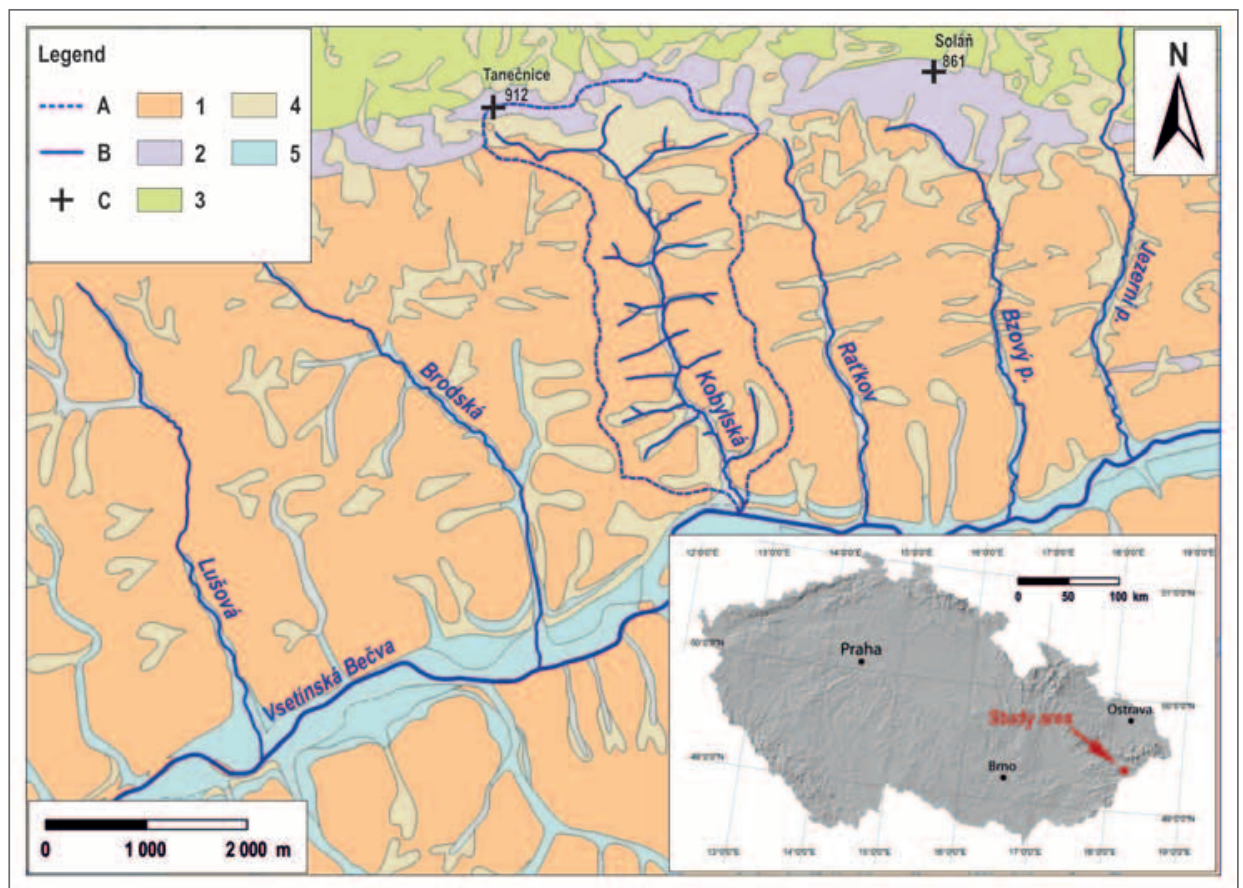

Obr. 1: Lokalizace studovaného území povodí vodního toku Kobylské. A - hranice povodí Kobylské; B - vodní tok; C - vrchol s názvem a výškou; 1 - vsetínské vrstvy zlínského souvrství; 2 - belovežské souvrství; 3 - ráztocké vrstvy soláňského souvrství; 4 - sedimenty sesuvu; 5 - fluviální a splachové kvartérní sedimenty (zdroj podkladových dat: Česká geologická služba, Výzkumný ústav vodohospodářský T. G. Masaryka).

Fig. 1: The localization of the study area of Kobylská Stream. A - the Kobylská watershed; B - Stream; C - Mountain peak with the name and height; 1 - Vsetín layers of the Zlín Formation; 2 - Belovežské Formation; 3 - Ráztocké layers of the Soláň Formation; 4 - landslide sediments; 5 - fluvial and deluviofluvial Quaternary sediments (source of the background data: Czech Geological Survey, Research Institute of Water Management T. G. Masaryk).

Toto petrografické složení s sebou nese vysokou rozkolísanost $\mathrm{v}$ zrnitosti povrchové vrstvy sedimentů dna $\mathrm{v}$ podélném průběhu toku, kdy především jílovce snadno podléhají erozi a rozpadají se na jemné částice. Oproti tomu výskyt odolnějších klastů tvořených pískovci podmiňuje prrítomnost hrubších zrnitostních frakcí (tj. především štěrkové a valounové frakce) v dnových sedimentech studovaného toku. Horní úsek toku je stržovitého charakteru se strmými svahy přiléhajícími ke korytu, které zprostředkovávají prrísun koluviálního materiálu do koryta. Ve spodní části toku přechází koryto do údolí neckovitého tvaru v prříném profilu s částečně vyvinutou ř́ční nivou a terasami (Škarpich, Galia 2014).

Geologicky zájmové území spadá do račanské jednotky magurské skupiny př́krovů. Většina zájmového povodí je budována flyšovými vrstvami hornin $s$ břidlicemi, vápnitými jílovci a především metry mocnými turbiditními vápnitými pískovci s glaukonitem vsetínských vrstev zlínského souvrství (eocén-oligocén) (Krejčí 1991; Pesl 1993; Baroň et al. 2014). Vsetínské vrstvy dosahují mocnosti 1 700-2 300 m (Chlupáč et al. 2002). V horních partiích povodí se vyskytuje drobně rytmický flyš s rudohnědými a zelenošedými jílovci belovežského souvrství (paleocén-eocén), jehož mocnost většinou nepřesahuje $100 \mathrm{~m}$ (Chlupáč et al. 2002). Místy se v rámci tohoto souvrství objevují až několik desítek metrů mocné polohy hrubozrnných arkózových pískovců. V průběhu holocénu bylo povodí zasaženo intenzivní mělkou i hlubinnou sesuvnou činností (Krejčí 1991; Pesl 1993; Pícha et al. 2006; Baroň et al. 2014).

Klima je charakteristické vyššími srážkovými úhrny a nižšími průměrnými teplotami. Na nejblíže umístěné stanici na Horní Bečvě (540 m n. m.) dosahují průměrné roční teploty $5,9^{\circ} \mathrm{C}$ a průměrný roční úhrn srážek $1125 \mathrm{~mm}$. Sněhová pokrývka je zde 44 dní v roce (Vitásek 1962). V povodí Kobylské se nevyskytuje žádná vodoměrná stanice, která by přinášela informace o průtočných poměrech a celkové hydrologické situaci v povodí. Na základě srovnání s nejblíže nacházejícím se povodím Lušová, pro které existují dostupné hydrologické údaje a jehož geologická stavba je téměř identická se zkoumaným tokem, můžeme uvažovat na podobnou hydrologickou situaci i v povodí toku Kobylské. U vodního toku Lušová (s plochou povodí $10,1 \mathrm{~km}^{2}$, viz obr. 1) je dlouhodobý průměrný průtok $0,2 \mathrm{~m}^{3} / \mathrm{s}$, průtok s dobou opakování 1 rok má hodnotu $8,3 \mathrm{~m}^{3} / \mathrm{s}$ a s dobou opakování 100 let 44,4 m³/s (zdroj: Povodí Moravy, s.p.). Největších vodností dosahují toky $\mathrm{v}$ této oblasti v období března až dubna $\mathrm{v}$ důsledku tání sněhu, a poté v letním období $\mathrm{v}$ důsledku intenzivní cyklonální činnosti.

Vysokogradientové toky v oblasti Vsetínských vrchů byly již v minulosti ovlivňovány přímými i nepřímými antropogenními zásahy. Odlesnění horské oblasti při Valašské kolonizaci v období 16. až 17. století způsobilo akceleraci erozních procesů (např. intenzivní vývoj strží) a navýšení přísunu sedimentů do koryt vodních toků (Galia et al. 2015; Galia, Škarpich 2017). Transport sedimentů ovlivnily a v současnosti stále ovlivňují také regulace koryt (hrazení a stabilizace břehů) realizované od poloviny 19. století. Hlavním důvodem pro tento př́stup úprav toků je stabilizace nivelety a zamezení nadměrného př́sunu sedimentů do dolních úseků toků s okolní zástavbou (Galia, Škarpich 2016). Hrazení nízkými spádovými stupni se u toku Kobylská nejvíce vyskytuje ve spodním úseku hlavního koryta, kde jsou tyto úpravy doplněné o opevnění břehů. 


\section{Metodika}

V první fázi výzkumu bylo přistoupeno $\mathrm{k}$ podrobnému fluviálně-geomorfologickému mapování v povodí Kobylské, které probíhalo od srpna do ř́jna 2016. Mapovány byly tvary reliéfu ovlivňující korytový systém Kobylské z hlediska zdrojnic sedimentů a překážek v jejich pohybu (sensu Fryirs et al. 2007).

Byly zmapovány přirozené geomorfologické tvary vyskytující se v korytě vodního toku, jakými jsou např. výchozy skalního podloží a na přiléhajících svazích např. břehové nátrže. $\mathrm{Z}$ antropogenních geomorfologických tvarů byly zmapovány stabilizační stupně, opevnění koryta atd.

Pro analýzu dnových sedimentů v korytě byla zvolena transektová metoda měření klastů dle Wolmana (1954). Bylo odebráno vždy 100 klastů povrchové vrstvy dnových sedimentů $\mathrm{v}$ předem vytipovaných (dle předešlého fluviálně-geomorfologického mapování) úsecích vodního toku. Povrchová vrstva sedimentů vzhledem $\mathrm{k}$ povaze zkoumaného bystřinného koryta téměř neobsahovala písčitou či ještě jemnější frakci, minimální velikost prostřední osy měřených klastů byla proto stanovena na $5 \mathrm{~mm}$. Subjektivní výběr klastů byl eliminován minimalizací očního kontaktu se dnem koryta. Většina klastů byla měřena posuvným měřítkem s přesností na $1 \mathrm{~mm}$. Rozměry balvanů, jež nemohly být ze dna vyzdvihnuty, byly měřeny s nižší přesností $(50 \mathrm{~mm})$ svinovacím metrem. Cílem bylo postihnout variabilitu zrnitosti sedimentů v závislosti na př́tomných korytových morfologiích, zdrojnicích sedimentů a antropogenních zásazích v povodí. Celkem byly takto odebrány a změřeny vzorky na 15 úsecích v podélném průběhu hlavního koryta Kobylské, nicméně zahrnuty byly také úseky vybraných prrítoků v pramenné oblasti. Celkové množství odebraných klastů činilo 1500 kusů. V každém z patnácti úseků byly pásmem a digitálním sklonoměrem zaměřeny také geometrické parametry koryta, mezi něž patřily sklon $(S)$ a šírka $(W)$. Z naměřených dat byly pro zhodnocení zrnitostních parametrů dnových sedimentů vypočteny (vždy pro daný úsek se 100 odebranými klasty) percentily $D_{5}, D_{25}, D_{50}, D_{75}$ a $D_{95}$, index velikosti $\left(D_{n}\right)$ a sféricita $\left(S_{p h}\right)$ klastů.

Pro jednotlivé úseky byly vypočteny průměrné hodnoty $D_{n}$ a $S_{p h}$. Index velikosti (nominální průměr) pro jedno zrno je dán vztahem $D_{n}=\left(a^{*} b^{*} c\right)^{1 / 3}$, kdy $a, b, c$ jsou jednotlivé osy klastů (dle Bunte, Abt 2001). Tento index je ukazatelem, který by měl indikovat vliv poproudového zmenšování klastů vlivem fluviálního opracování. Dalším zrnitostním parametrem je pak sféricita klastů, která poukazuje na geometrický tvar klastu. Pro jedno zrno je dána vztahem $S_{p h}=\left(b^{*} c / a^{2}\right)^{1 / 3}$, který nabývá hodnot $<0 ; 1>$, kdy 0 charakterizuje plochý neboli protáhlý klast podél nejdelší osy a a 1 značí klast nabývající tvaru koule (Bunte, Abt 2001).

Odhalení vzájemných vztahů mezi jednotlivými vypočtenými zrnitostními parametry dnových sedimentů a geometrickými parametry koryta pak přinesla následná korelační analýza. Statistická závislost pak byla určována na hladině významnosti $\alpha=0,05$, která určovala podmínku pro přijetí či zamítnutí nulové hypotézy. Dále bylo testováno na stejné hladině významnosti, zda ve studovaném toku existuje poproudový trend mediánu zrnitosti $\left(D_{50}\right)$ v závislosti na délce toku. Za tímto účelem byl použit Mann-Kendalův neparametrický test, kde je zjištěná míra závislosti namísto hodnoty klasického korelačního koeficientu vyjádřena tzv. Tau koeficientem. 

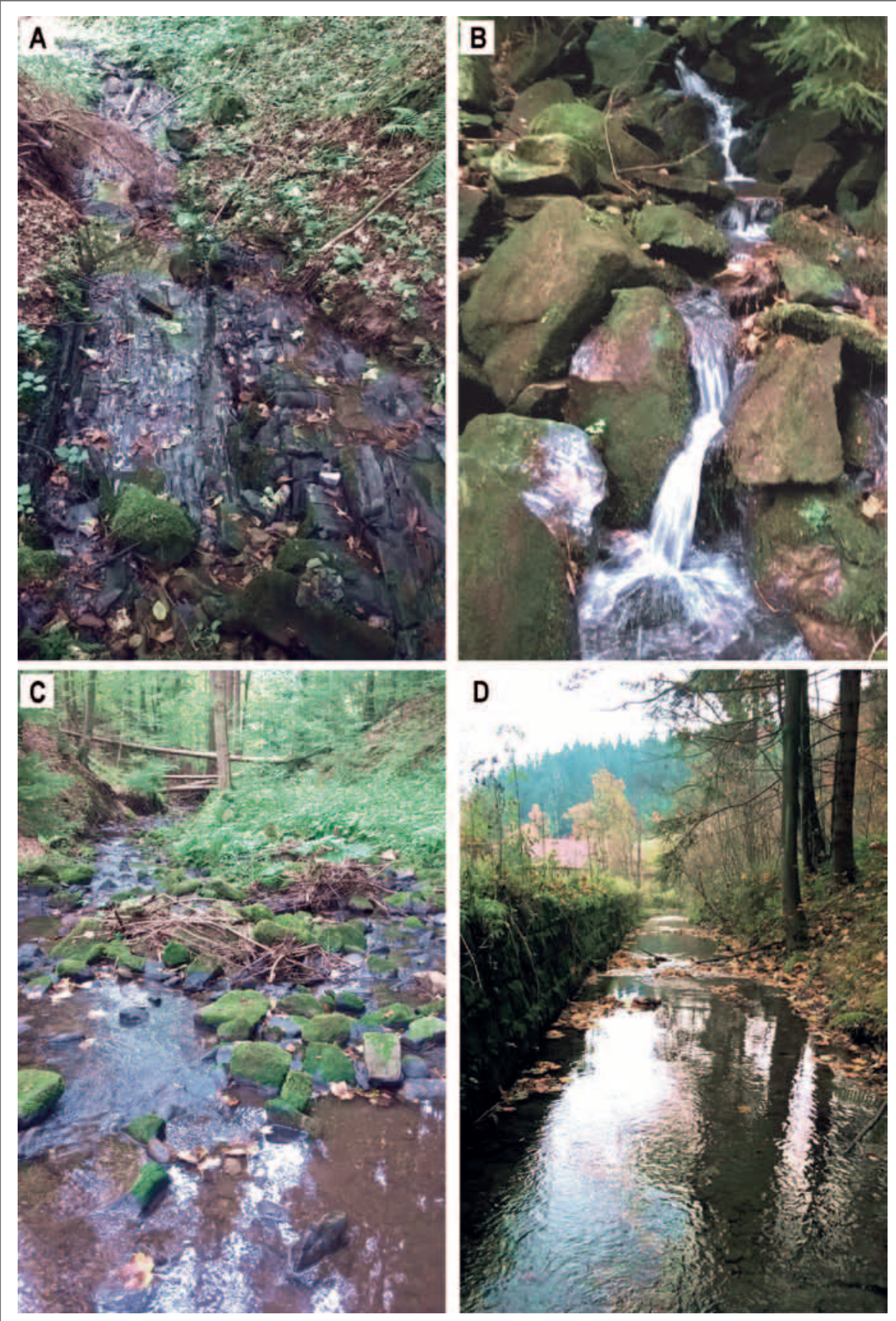

Obr. 3: A - jílovcové skalní podloží v horním úseku koryta Kobylské v ř. km 5,65; B - balvany tvořící morfologii koryta stupeň-tůň v oblasti sesuvu přiléhajícího ke korytu Kobylské, ř. km 4,18; C - přírodě blízký stav koryta v horním úseku koryta Kobylské v ř. km 3,62; D - koryto v dolním úseku Kobylské se stabilizací břehů a dřevěnými spádovými stupni v ř. km 1,72. Fig. 3: A - mudstone bedrock outcrop in the channel in upper section of the Kobylská Stream, $5.65 \mathrm{~km} ; \mathrm{B}$ - boulders which are creating step-pool morphology in channel in the landslide area in $4.18 \mathrm{~km}$; C - semi-natural channel in the upper section of the Kobylská Stream, $3.62 \mathrm{~km}$; $\mathrm{D}$ - bank stabilization and woody grade control structures in the channel in lower section of the Kobylská Stream in $1.72 \mathrm{~km}$.

\section{Výsledky a diskuze}

V celém podélném průběhu toku se projevuje charakteristický trend rozkolísanosti opracování a zrnitostního složení akumulovaných sedimentů v korytě. V horních úsecích vodního toku Kobylská (ř. km 3,0-5,4) je koryto stržovitého charakteru sevřeno strmými svahy s hodnotami sklonu koryta dosahujícími až $0,27 \mathrm{~m} / \mathrm{m}$ (viz obr. 2). V úseku koryta $\mathrm{v}$ r̆. $\mathrm{km} \mathrm{4,86-5,42} \mathrm{se} \mathrm{nachá-}$ zejí četné výchozy skalního podloží (viz obr. $2 \mathrm{~B}$ a $3 \mathrm{~A}$ ) převážně velmi erodibilních jílovcových vrstev belovežského souvrství. Tato situace se pak projevuje ve výskytu jemnějších frakcí dnového sedimentárního materiálu $\left(D_{50}\right.$ do $\left.40 \mathrm{~mm}\right)$ i přes vyšší hodnoty lokálního sklonu koryta (viz obr. 2A). Níže po toku se situace pozvolna mění a začínají se častěji objevovat pískovce vsetínských vrstev v podloží koryta (viz obr. 2B). $\mathrm{V}$ r. $\mathrm{km} \mathrm{3,9-4,25}$ protéká vodní tok úsekem s blokovým sesuvem, který přiléhá až těsně ke korytu. Tato situace se v korytě projevuje prrítomností velkých balvanů pískovců (délka osy $b$ až $650 \mathrm{~mm}$ ) podmiňujících výskyt charakteristické korytové morfologie stupeň-tůň (dle Montgomery, Buffington 1997) na obrázcích $2 \mathrm{~A}, 3 \mathrm{~B}$ a 4 . V podélném průběhu toku se pak tento stav odráží v zrnitosti dnových sedimentů ve formě výskytu hrubých frakcí $\left(D_{50}\right.$ až $50 \mathrm{~mm}$ ). V tomto úseku je koryto také velmi úzké, což se pravděpodobně projevuje selektivním transportem jemnějších frakcí již během mírně zvýšených průtoků. Níže po proudu se objevují další dva významnější sesuvy přiléhající až ke korytu (v ř. $\mathrm{km} \mathrm{3,0-3,25} \mathrm{a} \mathrm{v} \mathrm{ř.} \mathrm{km}$ 3,4-3,8), které také způsobují výskyt hrubších frakcí v dnových sedimentech (srovnej na obrázcích 2A a B a na obrázku 3C).

Níže po toku, v ř. $\mathrm{km}$ 0,0-3,0 přechází koryto do údolí neckovitého tvaru v příčném profilu. Koryto se zde rozšiřuje a snižuje se jeho lokální sklon dna (viz obr. 2B). Především dolní úsek koryta je antropogenně ovlivněn hrazením a opevněním břehů (viz obr. 3D). V ř. km 1,19-2,54 je v korytě vybudováno množství dřevěných a kamenných spádových stupňů. Spádové stupně snižují podélný sklon a zpomalují transport sedimentů. Charakteristické je zde hrubnutí sedimentů ( $D_{50}$ až do $49 \mathrm{~mm}$ ), pravděpodobně v souvislosti s efektem hladové vody 
ve smyslu Kondolfa (1997), i přes nižší hodnoty lokálního sklonu koryta. Tento stav je také ovlivněn materiálem pískovcových hornin v podloží, které se do koryta dostávají z břehových nátrží (rovnoměrně se vyskytujících v celém podélném průběhu toku) a sesuvů (v úseku ř. km 3,00-4,25). Klasty pískovců jsou pak méně erodibilní a hůře opracovatelné, což se také podílí na hrubnutí dnových sedimentů. Menší sesuvy přiléhající až těsně ke korytu, např. v ř. km 1,3-1,4, 1,6-1,7 a 2,3-2,45, jsou z hlediska dodávky sedimentárního materiálu ovlivněny stabilizací břehů omezující boční dodávku sedimentů (viz např. obr. 3D) a na výsledném zrnitostním složení dnových sedimentů se neprojevují. Ačkoliv je možno ve studovaném toku obecně pozorovat relativně jemnější dnové sedimenty v nejvyšší části povodí a posléze vyšší hodnoty zrnitosti sedimentů ve středních a dolních partiích toku (viz obr. 2A), výsledkem celkové rozkolísanosti zrnitosti sedimentů je pouze nesignifikantní hodnota Mann-Kendallova testu $($ Tau $=-0,33, p=0,093)$ pro hodnotu $D_{50}$ v závislosti na délce toku. Záporná hodnota Tau koeficientu však ukazuje na tendenci poproudového hrubnutí mediánu zrnitosti v rámci studovaného průběhu toku.

Korelační analýza přinesla informace o vzájemných závislostech mezi zrnitostními parametry dnových sedimentů a geometrickými parametry koryta (viz tab. 1). Z výsledků analýzy je patrné, že sklon koryta $(S)$ poukazuje na nepř́ímou závislost se zrnitostními parametry percentilů $D_{25}$, $D_{50}, D_{75}$ a indexu velikosti klastů $D_{n}$. To znamená, že čím větší je lokální sklon koryta, tím jemnější zrnitostní frakce jsou v daném úseku zastoupeny. Tento pro říční systémy atypický stav lze vysvětlit litologickou stavbou území. V horních partiích povodí je podloží koryta budováno především drobně rytmickým flyšem s rudohnědými a zelenošedými jílovci, které představují hlavní zdroj sedimentů pro vodní tok. Koryto v tomto úseku má stržovitý charakter s lokálním sklonem dosahujícím hodnoty až $0,27 \mathrm{~m} / \mathrm{m}$ (v ř. km 3,2-5,4 je průměrný lokální sklon $0,19 \mathrm{~m} / \mathrm{m})$. Júlovcové horniny pak představují velmi erodibilní a rychle rozpadavý materiál, který se pak v zrnitostním složení projevuje zastoupením většího množství jemnějších frakcí v těchto úsecích s vyšším sklonem. Oproti tomu v dolním úseku, kde je sklon koryta nižší s maximálním lokálním sklonem $0,16 \mathrm{~m} / \mathrm{m}$ (v ř. km 0,0-3,2 je průměrný lokální sklon $0,13 \mathrm{~m} / \mathrm{m})$, se vyskytují především hrubší frakce relativně odolných glaukonitických pískovců, které se nacházejí v podloží toku a tvoří zde hlavní zdrojový materiál dnových sedimentů.

Erodibilita jílovců dostávajících se do koryta v horních úsecích Kobylské je pak podpořena statisticky signifikantním vztahem neprímé závislosti mezi šírkou
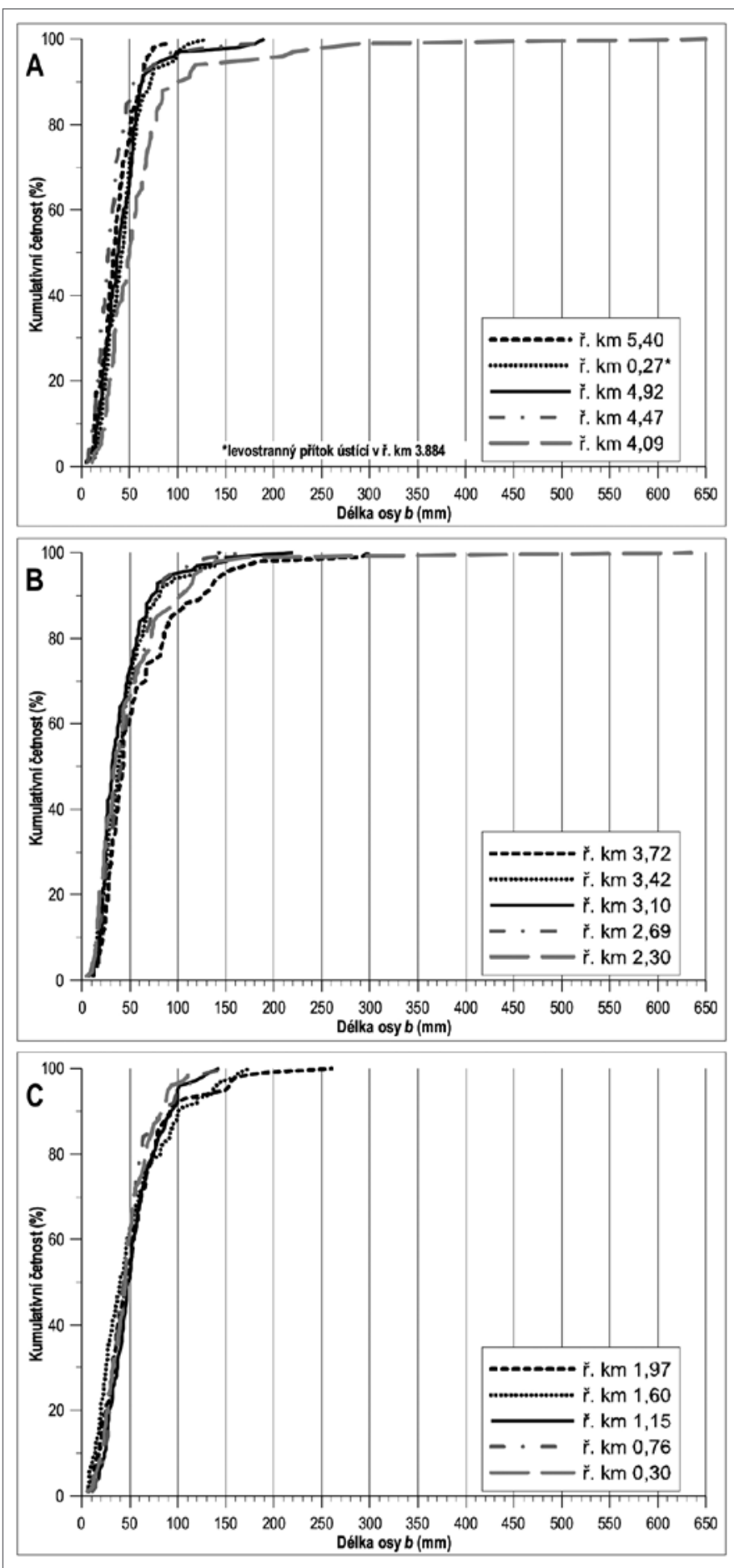

Obr. 4: Zrnitostní křivky znázorňující porovnání naměřených délek osy $b \mathrm{v}$ podélném průběhu toku Kobylská; A - říční km 5,40-4,09; B - říční km 3,72-2,30; C - říční km 1,97-0,30.

Fig. 4: Contribution of grain-size parameters of the $b$ axis in longitudinal course of the Kobylská stream; A - river km 5.40-4.09; B - river km 3.72-2.30; C - river km 1.97-0.30.

koryta $(W)$ a indexem sféricity $\left(S_{p h}\right)$. Rychlá rozpadavost se projevuje ve vyšších hodnotách sféricity klastů v horních partiích toku charakterizovaných užším korytem oproti odolnějším horninám pískovců tvořících materiál dnových sedimentů v dolních úsecích se širším korytem. 


\section{Závěr}

Zrnitostní složení sedimentů dna je v korytě Kobylské charakteristické vysokou rozkolísaností v podélném průběhu toku. Tato situace je pro vysokogradientové toky v oblasti Karpat typická (Škarpich et al. 2010). Uplatňuje se zde střídání odolnějších a méně odolných hornin v podloží toku, lokálně omezené vstupy sedimentů z břehových nátrží nebo z přilehlých sesuvů a antropogenní ovlivnění koryt (výstavba stabilizačních stupňů, stabilizace břehů) (Galia, Škarpich 2013; Škarpich, Galia 2014).

V horní části povodí má koryto stržovitý charakter často s vystupujícím skalním podložím. Ve středním úseku koryto postupně přechází do neckovitého tvaru údolí a významně se zde projevují sesuvy z hlediska dodávky hrubších sedimentů do koryta. V dolní části je koryto velmi ovlivněno antropogenní činností. Stabilizace břehů (především kamenná rovnanina) odpojují boční zdrojnice od koryta a četné spádové stupně (viz obr. 2) zpomalují chod sedimentů v podélném průběhu toku. Tyto úpravy se tak rovněž mohou projevovat na pozorovaném trendu hrubnutí dnových sedimentů z hlediska efektu tzv. hladové vody (ve smyslu Kondolfa 1997).

V korytě Kobylské se významně odráží vliv horninového složení na zrnitostních parametrech dnových sedimentů. $\mathrm{V}$ pramenných úsecích Kobylské s většími lokálními sklony dna se vyskytují v podloží málo odolné jílovce, které se dostávají do koryta a projevují se ve výskytu jemnějších frakcí dnových sedimentů. Níže po proudu v dolních úsecích s nižším lokálním sklonem koryta se v podloží vyskytují odolné pískovce, které jsou prostřednictvím sesuvů a břehových nátrží dodávány do koryta. V těchto prrípadech pak nastává hrubnutí dno- vých sedimentů. Tento vliv podložní litologie potvrdila i korelace vzájemných vztahů mezi lokálním sklonem koryta a zrnitostními parametry dnových sedimentů. Touto analýzou bylo zjištěno, že čím větší je lokální sklon koryta, tím jemnější zrnitostní frakce jsou v daném úseku zastoupeny. Dle výzkumů Galia, Škarpich (2013) nebo Galia et al. (2015) v jiných vysokogradientových korytech flyšových Karpat lze konstatovat, že vyšší lokální sklon dna se v zrnitostním složení dnových sedimentů obvykle projevuje ve výskytu hrubších frakcí, což koresponduje se základními teoriemi říčních systémů. U koryta Kobylské se však tento trend neprojevuje, resp. je opačný, což lze přisoudit především vlivu výše zmíněné litologie povodí.

\section{Poděkování}

Př́spèvek vznikl za podpory interního grantu Ostravské univerzity SGS05/PřF/2017-2018. Autoři děkují Ondřeji Bábkovi a anonymnímu recenzentovi za cenné pripominky $\checkmark$ recenzním ř́zení.

\section{Literatura}

Baroň, I., Bíl, M., Bábek, O., Smolková, V., Pánek, T., Macur, L. (2014). Effect of slope failures on river-network pattern: A river piracy case study from the flysch belt of the Outer Western Carpathians. - Geomorphology, 214, 356-365. http://dx.doi.org/10.1016/j.geomorph.2014.02.017

Brierley, G. J., Fryirs, K. A. (2005). Geomorphology and River Management: applications of the river styles framework. - 398 pp. Blackwell Publishing Oxford.

Bunte, K., Abt, S. R. (2001). Sampling surface and subsurface particle-size distributions in wadable gravel-and cobble-bed streams for analyses in sediment transport, hydraulics, and streambed monitoring. - General Technical Report RMRS-GTR-74. Fort Collins, CO: U.S. Department of Agriculture, Forest Service, Rocky Mountain Research Station, 1-428.

Fryirs, K. A., Brierley, G. J., Preston, N. J., Kasai, M. (2007). Buffers, barriers and blankets: The (dis)connectivity of catchment-scale sediment cascades. - Catena, 53, 49-67.

Galia, T., Škarpich, V. (2013). Korytové sedimenty a geomorfologické procesy vysokogradientových toků ve flyši Moravskoslezských Beskyd. - Geologické Výzkumy na Moravě a ve Slezsku, 20, 17-21.

Galia, T., Škarpich, V., Hradecký, J. (2015). Connectivity of the coarsest fraction in headwater channels: imprints of fluvial processes and debris-flow activity. - Geografiska Annaler: Series A, Physical Geography, 97, 437-452. https://doi.org/10.1111/ geoa.12086 
Galia, T., Škarpich, V. (2016). Do the coarsest bed fraction and stream power record contemporary trends in steep headwater channels? - Geomorphology, 272, 115-126. http://dx.doi.org/10.1016/j.geomorph.2015.07.047

Galia, T., Škarpich, V., Hradecký, J., Přibyla, Z. (2016). Effect of grade-control structures at various stages of their destruction on local channel parameters. - Geomorphology, 253, 305-317. http://dx.doi.org/10.1016/j.geomorph.2015.10.033

Galia, T., Škarpich, V. (2017). Response of bed sediments on the grade-control structure management of a small piedmont stream. - River Research and Applications, 33, 4, 483-494. https://doi.org/10.1002/rra.3111

Chlupáč, I., Brzobohatý, R., Kovanda, J., Stráník, Z. (2002). Geologická minulost České republiky. - 436. s. Akademie věd České republiky Praha.

Kondolf, G. M. (1997). Hungry water: effects of dams and gravel mining on river channels. - Environmental Management, 21, $533-551$.

Krejčí, O. (1991). Geologická mapa ČR 1 : 50000 - list 25-41, Vsetín. - Český geologický ústav.

Montgomery, D. R., Buffington, J. M. (1997). Channel-reach morphology in mountain drainage basins. - GSA Buletin, 5, 596-611.

Montgomery, D. R., Buffington, J. M. (1998). Channel processes, classification and response. In: Naiman, R. J., Bilby, R. E. (eds). River Ecology and Management: Lessons from the Pacific Coastal Ecoregion. - 13-42. Springer, New York.

Pesl, V. (1993). Geologická mapa ČR 1 : 50000 - list 25-23, Rožnov pod Radhoštěm. - Český geologický ústav.

Pícha, F. J., Stráník, Z., Krejčí, O., Kirchner, K. (2006). Geology and Hydrocarbon Resources of the Outer Western Carpathians and their Foreland, Czech Republic. - In: Golonka, J., Pícha, F. J. (eds), The Carpathians and Their Foreland: Geology and hydrocarbon resources. - AAPG Memoir, 49-175.

Schumm, S. A. (1977). The Fluvial System. - 338 pp. John Wiley and Sons. New York.

Škarpich, V., Galia, T., Hradecký, J., Peč, J. (2010). Identifikace (dis)konektivit vodních toků za využití makrogranulometrické analýzy korytových sedimentů (Moravskoslezské Beskydy). - Geologické výzkumy na Moravě a ve Slezsku, 17, 199-204.

Škarpich, V., Galia, T. (2014). Projevy zdrojových oblastí sedimentů v zrnitostním složení korytových akumulací vodních toků v reliéfu budovaném flyšovými horninami. - Geologické výzkumy na Moravě a ve Slezsku, 21, 33-37.

Škarpich, V., Kašpárek, Z., Galia, T., Hradecký, J. (2016). Antropogenní impakt a jeho odezva v morfologii koryt beskydských štěrkonosných toků: prŕíkladová studie řeky Ostravice, Česko. - Geografie, 121, 99-120.

Vitásek, F. (1962). Moravské zeměpisné krajiny. - Práce Brněnské základny Československé akademie věd, ročník XXXIV, sešit 4. - 147 s. Nakladatelství československé akademie věd, Praha.

Wolman, M. G. (1954). A method of sampling coarse bed material. - American Geophysical Union, 36, 951-956.

Wohl, E. E., Merritt, D. M. (2008). Reach-scale channel geometry of mountain streams. - Geomorphology, 93, 168-185. 